\title{
Testosterone suppression in the treatment of recurrent or metastatic prostate cancer - A Canadian consensus statement
}

Laurence Klotz ${ }^{1}$; Bobby Shayegan ${ }^{2}$; Chantal Guillemette ${ }^{3}$; Loretta L. Collins ${ }^{4}$; Geoffrey Gotto ${ }^{5}$; Dominique Guerette ${ }^{3}$; Marie-Paule Jammal ${ }^{6}$; Tom Pickles ${ }^{7}$; Patrick O. Richard ${ }^{8}$; Fred Saad ${ }^{9}$ ${ }^{1}$ University of Toronto, Toronto, ON; ${ }^{2}$ McMaster University, Hamilton, ON; ${ }^{3}$ Université Laval and CHU de Québec-Université Laval, Quebec City, QC; ${ }^{4}$ Kaleidoscope Strategic, Toronto, ON; ${ }^{5}$ University of Calgary, Calgary, $\mathrm{AB} ;{ }^{6}$ Université de Montréal, Laval, QC; ${ }^{7} \mathrm{BC}$ Cancer, Vancouver, BC; ${ }^{8}$ Centre Hospitalier Universitaire de Sherbrooke, Centre de recherche du CHUS, Sherbrooke, QC; ${ }^{9}$ Centre Hospitalier de l’Université de Montréal, Montreal, QC; Canada

Acknowledgment: The authors thank Deanna McLeod of Kaleidoscope Strategic for research, editorial and administrative support in preparing the consensus statement.

Funding: Publication support services were funded in an independent fashion by Sanofi Canada. The opinions presented in the paper represent those of the authors and not the sponsor; none of the clinical authors were paid for writing this article. The sponsor did not contribute to the design or development of the article and did not see the manuscript prior to submission.

Cite as: Can Urol Assoc J 2017 Dec. 19; Epub ahead of print. http://dx.doi.org/10.5489/cuaj.5116

Published online December 19, 2017

$* * *$

\section{Abstract}

Testosterone suppression, achieved through orchiectomy or medically-induced androgen deprivation therapy (ADT), is a standard treatment for men with recurrent and metastatic prostate cancer. Current assay methods demonstrate the capacity for testosterone suppression to $<0.7$ $\mathrm{nmol} / \mathrm{l}$, and clinical data support improved outcomes from ADT when lower levels are achieved. Practical clinical guidelines are warranted to facilitate adoption of $0.7 \mathrm{nmol} / \mathrm{l}$ as the new standard castrate testosterone level.

A pan-Canadian group of experts, representing diverse clinical specialties, identified key clinical issues, searched and reviewed relevant literature, and developed consensus statements on testosterone suppression for the treatment of prostate cancer. The expert panel found that current evidence supports the clinical benefit of achieving low testosterone levels during ADT, and encourage adoption of $\leq 0.7 \mathrm{nmol} / 1$ as a new castrate level threshold. The panel recommends 
regular monitoring of testosterone (e.g., every 3-6 months) and PSA levels as clinically appropriate (e.g., every 3-6 months) during ADT, with reassessment of therapeutic strategy if testosterone is not suppressed or if PSA rises regardless of adequate testosterone suppression. The panel also emphasizes the need for greater awareness and education regarding testosterone assay specifications, and strongly promote the use of mass spectrometry-based assays to ensure accurate measurement of testosterone at castrate levels.

\section{Introduction}

Prostate cancer remains the most common cancer diagnosis in men in Canada and is still among the top 3 leading causes of cancer death [1]. Men with early disease generally have a good prognosis; however, disease recurrence after initial treatment remains significant [2-5]. Androgen deprivation therapy (ADT) is the standard first-line treatment for men with recurrent or metastatic prostate cancer [6]. The goal of ADT is suppression of testosterone, an androgenic hormone associated with growth and progression of prostate cancer [7]. There is mounting evidence that suppression of patients' testosterone levels below the historical castrate standard of $1.7 \mathrm{nmol} / \mathrm{l}$ (e.g., $\leq 0.7-1.1 \mathrm{nmol} / \mathrm{l}$ ), is associated with improved treatment outcomes versus patients with higher levels [8-13]. Although data support a relationship between lower testosterone levels and clinical benefit, many questions remain on how to translate this knowledge to practice [13]. This Canadian Consensus summarizes evidence and provides guidance developed by a multi-disciplinary panel of experts to assist practicing clinicians in implementing a lower castrate testosterone threshold during ADT for prostate cancer.

\section{Methods}

A Steering Committee of 4 clinical experts surveyed clinical issues among participants who represented multiple clinical specialties (academic/community urology, radiation oncology, and clinical biochemistry) and provided a pan-Canadian perspective. The Steering Committee conducted a topic-directed literature search, and developed proposed consensus statements that addressed clinical issues. All statements were graded by level of supporting evidence and level of consensus according to National Comprehensive Cancer Network (NCCN) consensus methodology (Table 1) [14, 15]. Between September 5-October 11, 2017, experts virtually reviewed and voted on proposed consensus statements. Statements not approved via $\geq 85 \%$ consensus were revised and confirmed at $>85 \%$ in a second round of review and voting.

\section{Consensus statements}

\section{Clinical benefit of low testosterone during ADT}

Studies of the association of testosterone suppression level during ADT and outcomes of therapy have consistently demonstrated clinical benefit and importance of greater testosterone suppression during ADT $[8-12,16]$. Prospective studies of ADT for the treatment of prostate 
cancer have assessed a range of testosterone level thresholds below the historical castrate level standard, including $\leq 0.7, \leq 0.9, \leq 1.0$, or $\leq 1.1 \mathrm{nmol} / 1$, and demonstrated that patients achieving these low levels had longer time to castration resistant prostate cancer (CRPC) or death than their counterparts with respectively higher levels (Table 2) [8-12]. The largest prospective trial enrolled 626 patients with localized or locally advanced prostate cancer with treatment via orchiectomy, or LHRH agonist (LHRHa) therapy plus a non-steroidal anti-androgen for at least 4 weeks $[8,16]$. Assessment of serum testosterone levels was completed every 2 months and results indicated that lower testosterone level was associated with longer time to CRPC. Analysis of testosterone levels during the first year of ADT demonstrated that time to CRPC was significantly improved for patients with nadir testosterone levels $\leq 0.7 \mathrm{nmol} / 1$, compared with those with levels between $>0.7 \mathrm{nmol} / \mathrm{l}$ and $<1.7 \mathrm{nmol} / 1$ or $\geq 1.7 \mathrm{nmol} / 1$ ( $p=0.015)$. Median times to CRPC were 10.0, 7.21 and 3.62 years, respectively. Additionally, median testosterone level $>0.7 \mathrm{nmol} / \mathrm{l}$ was associated with a higher risk of developing CRPC compared with lower levels $(\mathrm{p}=0.02$; Table 2) $[8,16]$.

In retrospective analyses of ADT outcomes, including rates of testosterone breakthrough, progression-free survival (PFS), cause-specific survival (CSS), or overall survival (OS), relative to testosterone suppression level, 4 out of 6 studies demonstrated improved outcomes among patients with testosterone levels of $\leq 0.7 \mathrm{nmol} / 1$ or $\leq 1.1 \mathrm{nmol} / 1$ versus respectively higher levels [17-20].

Of the thresholds examined, ranging from $\leq 0.7$ to $\leq 1.1 \mathrm{nmol} / 1$, the greatest number of studies supported a testosterone suppression threshold of $0.7 \mathrm{nmol} / \mathrm{l}$. There was a clinical benefit associated with concentrations at or below this cut-off [8, 9, 12, 16-18]. These data suggest that $0.7 \mathrm{nmol} / \mathrm{l}$ is an appropriate target testosterone level during ADT [16]. Based on the available evidence, we offer the following consensus statements.

\section{CONSENSUS STATEMENT 1}

In men receiving $\mathrm{ADT}$ for prostate cancer:

1a. There appears to be a clinical benefit associated with achieving a serum testosterone level of $\leq 0.7 \mathrm{nmol} / 1$ (Category $2 \mathrm{~A}$ )

1b. Testosterone suppression to $\leq 0.7 \mathrm{nmol} / 1$ is a reasonable clinical goal (Category 2A)

Although current evidence supports adoption of a new castrate level threshold of $\leq 0.7 \mathrm{nmol} / 1$ during ADT, additional prospective studies are necessary to determine and validate the optimal threshold associated with the greatest therapeutic benefit [16]. 


\section{Application}

\section{2a. Frequency of testosterone and PSA testing}

Given the benefit of achieving a target testosterone level of $\leq 0.7 \mathrm{nmol} / 1$, testosterone assay timing is important. Current guidelines support the goal of achieving castrate testosterone levels within the first year of ADT [8, 21, 22]. Although new dissolvable implants and gel-based depots permit more flexible dosing frequencies, physicians should consider monitoring testosterone every 3-6 months, or as appropriate, during the first year to ensure target levels are achieved [8, 21-23]. Once the target threshold has been reached, lengthening the monitoring frequency as appropriate for a patient's risk of relapse would be acceptable.

As a marker of testosterone signaling and disease control or potential progression, regular monitoring of prostate-specific antigen (PSA) level is also recommended every 3-6 months, or as clinically appropriate $[13,16,21,22]$.

\section{CONSENSUS STATEMENT 2a}

Prescribers of ADT should perform regular monitoring of testosterone and PSA levels throughout the first year of treatment (Category 2A)

\section{2b. Accuracy of testing and collaboration with clinical labs}

The first hormone assays were developed decades ago, and their limited sensitivity had a significant influence in setting the historical castrate testosterone level standard of $1.7 \mathrm{nmol} / \mathrm{l}$ [24-27]. More recent technological advances in assay methodology include improved immunoassays (IA) and the development of mass spectrometry (MS), allowing greater sensitivity and accuracy of detection [25, 26, 28, 29]. IA has long been the standard method for testosterone measurement and is most commonly used [30]. However, there are significant limitations in specificity, and therefore accuracy of IAs, particularly at the new target testosterone threshold of $\leq 0.7 \mathrm{nmol} / 1$ [31-38] (Figure 1A). A recent study by Morote et al. demonstrated the lack of reliability of IAs in the context of ADT for prostate cancer [38]. This prospective study, enrolling 249 patients, compared two commercially available IAs and reported that the methods showed different behaviors, with modest correlation between them. One method showed only $24.9 \%$ of patients with levels below the threshold of $0.7 \mathrm{nmol} / \mathrm{l}$, and the other indicated that over $77.5 \%$ of patients had testosterone levels below $0.7 \mathrm{nmol} / \mathrm{l}$. These data suggest that IA methods could compromise the monitoring of castrate testosterone levels and therefore evaluation of ADT. 
In contrast, several studies have demonstrated that the variability of results obtained with different MS based assays is substantially less than those obtained by IA methods (especially at low testosterone concentrations) and confirmed that the threshold of sensitivity of MS is sufficient for monitoring testosterone in the context of ADT (Figure 1B) [31, 33, 39-41]. As an example, an externally validated LC-MS/MS method [40,42] was used to assess testosterone levels in men on ADT [40]. A total of 34 men underwent surgical castration and 32 men received an LHRHa. Serum samples were collected and analyzed by LC-MS/MS $\geq 3$ months from the date of surgery or initiation of medical ADT. Results showed that men on LHRHa had significantly lower testosterone levels (median $4.0 \mathrm{ng} / \mathrm{dl}$ [0.14 nmol/l], range $<2.9$ to $20.2 \mathrm{ng} / \mathrm{dl}$ [ $<0.1$ to 0.7 $\mathrm{nmol} / \mathrm{l}]$ ) compared to those surgically castrated (median $9.2 \mathrm{ng} / \mathrm{dl}[0.32 \mathrm{nmol} / \mathrm{l}]$, range $<2.9$ to $28.8 \mathrm{ng} / \mathrm{dl}[<0.1$ to1.0 nmol/l], $\mathrm{p}<0.001$ ), demonstrating the ability of this method to accurately differentiate testosterone levels in the castrate range [40].

Use of LC-MS/MS is becoming more prevalent in clinical labs, while also accessible through out-sourcing of sample analysis to validated LC-MS/MS reference laboratories [31, 39, 40]. Average turnaround times for outsourced samples range from 7 to 10 days. LC-MS/MS should be considered the gold standard for testosterone assay at levels $\leq 0.7 \mathrm{nmol} / 1$ and sought out as a preferred method of testing over IA. Indeed, the American Endocrine Society recommends use of only MS for the measurement of testosterone at low levels [33, 39, 41]. If regular use of LC-MS/MS for low level testosterone assay is either unavailable or not feasible through on-site analysis or out-sourcing, IA methods validated against MS may be considered. An important aspect in establishing assays for testosterone measurement in local clinical laboratories is participation in accuracy-based external quality assessment (EQA) and standardization programs for both MS and IA. EQA programs ensure assay reliability over time and allow standardization of testosterone measures across laboratories (see Appendix for details on measures of accuracy) [41, 43-48]. These assessments are essential to ensuring ongoing reliability of results at low testosterone concentrations.

Given the potential variability in testing methods available at clinical labs, clinicians should clearly express their assay needs by requesting low/castrate testosterone levels for patients on ADT. They may also consider adding notation to the requisition form or including an accompanying note or additional material (e.g., information presented in Appendix) to reinforce the need for use of an assay method that is accurate at low testosterone levels. 


\section{CONSENSUS STATEMENTS $2 \mathrm{~b}-1$ and $2 \mathrm{~b}-2$}

2b-1. For men with recurrent or metastatic prostate cancer receiving ADT

- Immunoassay (IA) may not be sufficiently specific, sensitive, accurate or reproducible in the detection of castrate level serum testosterone unless the method is externally validated against MS

- Validated liquid chromatography tandem mass spectrometry (LC-MS/MS) methods are the gold standard for castrate level testosterone assays, with adequate specificity, sensitivity, and accuracy at low concentrations $(\leq 0.7$ $\mathrm{nmol} / \mathrm{l})$

(Category 2A)

2b-2. Clinicians treating men with recurrent or metastatic prostate cancer receiving ADT

- Should consider encouraging access to validated testosterone assays, preferably by LC-MS/MS, either at their center or through collaboration with other centers

- Should consider ways to communicate the need for testosterone assay in the castrate range and consider providing additional notation with the requisition to promote reliable and accurate testosterone assessment at low levels (Category 2A)

\section{Management}

Clinical management strategies are necessary to address cases in which testosterone and/or PSA thresholds are not achieved. Testosterone levels during ADT reflect the efficacy of treatment, while the serum PSA concentrations are a reflection of disease control. Preferably, both testosterone and PSA levels remain low $(\leq 0.7 \mathrm{nmol} / 1$ and $\leq 2 \mathrm{ng} / \mathrm{ml}$, respectively), but if either begin to rise, reassessment and a change in therapeutic strategy may be warranted. There are two general scenarios defined by testosterone level (i.e., inadequate vs adequate testosterone suppression) that can be used to guide treatment strategy, with further differentiation according to relative PSA levels (Figures 2 and 3).

\section{3a. Inadequately suppressed testosterone}

The first scenario applies to patients receiving ADT and demonstrating consistently inadequate testosterone suppression, as assessed via testosterone measurements taken during continuous ADT or the on-therapy intervals of intermittent ADT within the first year $[8,16]$. These patients may have either stable or rising PSA levels. For those with stable PSA (non-metastatic or metastatic), a testosterone level above $0.7 \mathrm{nmol} / \mathrm{l}$ may indicate treatment failure and alternate 
medical or surgical treatments should be considered $[8,16]$ (Figure 2). For those with rising PSA, inadequate testosterone suppression may also indicate treatment failure. For non-metastatic or metastatic disease, alternate medical or surgical treatments should be considered [16]. In either case, combined androgen blockade with a non-steroidal anti-androgen may provide protection against the effects of failure to suppress serum testosterone below $0.7 \mathrm{nmol} / \mathrm{l}$ [18]. However, for those with metastatic disease, testosterone level $<1.7 \mathrm{nmol} / \mathrm{l}$ and PSA $>2 \mathrm{ng} / \mathrm{ml}$, treatment for CRPC following CUA-CUOG guidelines should be implemented [49].

\section{CONSENSUS STATEMENT 3a}

For men with recurrent or metastatic prostate cancer receiving ADT, a testosterone level consistently above the target threshold of $0.7 \mathrm{nmol} / \mathrm{l}$ may indicate treatment failure and alternate medical or surgical therapy should be considered (Category 2A)

\section{3b. Adequately suppressed testosterone}

The second scenario applies to patients receiving ADT with adequately suppressed testosterone. In this case, stable PSA indicates effective disease control and patients should continue their current ADT (Figure 3). Rising PSA in the context of suppressed testosterone may indicate CRPC [16]. For non-metastatic patients, addition or withdrawal of an anti-androgen may be considered, while treatment for the management of CRPC [49] is recommended for patients with metastatic disease. For patients receiving intermittent ADT, rising PSA levels during the offtreatment interval occur normally, prompting re-initiation of therapy, usually when the PSA reaches a level of $10-20 \mathrm{ng} / \mathrm{ml}[16]$.

\section{CONSENSUS STATEMENT 3b}

For men with recurrent or metastatic prostate cancer receiving ADT with adequate testosterone suppression, rising PSA levels require consideration of alternate therapy, including treatment for CRPC (Category 2A)

The current recommendations for management of recurrent or metastatic prostate cancer are based on available evidence and expert consensus regarding standards of current practice. The described approaches may also apply in the treatment of locally advanced/high risk disease with or without local therapy. During ADT, a castrate testosterone level of $\leq 0.7 \mathrm{nmol} / 1$ is a reasonable and practical goal. Understanding the implications of testosterone levels relative to PSA levels during treatment guides therapeutic strategy. While low testosterone correlates with 
an improved outcome, explicit clinical evidence for the benefit of reducing testosterone in men whose levels are not fully suppressed is limited. Further prospective research is necessary to confirm that adjusting therapy in inadequately suppressed patients to achieve testosterone suppression $\leq 0.7 \mathrm{nmol} / 1$ will result in improved treatment outcomes [16].

\section{Knowledge translation}

Identification, clinical assessment and documentation of the link between achieving lower testosterone levels during ADT and improved outcomes for prostate cancer patients are essential first steps in improving patient care. However, distribution of knowledge and translation to clinical application are necessary to ensure a real clinical impact. A recent survey of Canadian clinicians treating prostate cancer suggests a fundamental knowledge gap regarding the practical steps needed to ensure maximal testosterone suppression during ADT [13]. Among surveyed Canadian urologists, uro-oncologists, and radiation oncologists treating prostate cancer, including community urologists, approximately one-third were unaware of the lower limit of detection of the castrate testosterone assays used. Approximately $40 \%$ were monitoring testosterone regularly (e.g., every 3-6 months, or prior to each LHRHa injection), and the majority were unaware of the testosterone assay method used in their centre/laboratory [13]. There is a need for increased awareness regarding the importance and implications of testosterone suppression during ADT, as well as a baseline level of technical knowledge for proper selection and interpretation of testosterone assay data to guide assay selection and ensure detectability at or below $0.7 \mathrm{nmol} / \mathrm{l}$.

\section{Summary and Conclusions}

Optimal care for men receiving ADT for prostate cancer includes the testosterone suppression goal of $\leq 0.7 \mathrm{nmol} / \mathrm{l}$, regular monitoring of testosterone and PSA levels, and reassessment of therapeutic strategy if (1) serum testosterone is not suppressed or (2) PSA rises regardless of adequate testosterone suppression. We encourage clinicians to be aware of the assays used to assess testosterone level in samples from patients on ADT, and to ensure that the laboratories selected provide LC-MS/MS analysis calibrated for low testosterone levels, whether it is achieved in-house or via outsourcing. 


\section{References}

1. Canadian Cancer Society's Advisory Committee on Cancer Statistics. Canadian Caner Statistics 2017.

http:/www.cancer.ca/ /media/cancer.ca/CW/publications/Canadian\%20Cancer\%20Statistics/Ca nadian-Cancer-Statistics-2017-EN.pdf; Accessed Oct 10, 2017.

2. Han M, Partin AW, Piantadosi S et al. Era specific biochemical recurrence-free survival following radical prostatectomy for clinically localized prostate cancer. J Urol 2001; 166: 416419.

3. Han M, Partin AW, Pound CR et al. Long-term biochemical disease-free and cancerspecific survival following anatomic radical retropubic prostatectomy. The 15-year Johns Hopkins experience. Urol Clin North Am 2001; 28: 555-565.

4. Han M, Partin AW, Zahurak M et al. Biochemical (prostate specific antigen) recurrence probability following radical prostatectomy for clinically localized prostate cancer. J Urol 2003; 169: 517-523.

5. Pound CR, Partin AW, Eisenberger MA et al. Natural history of progression after PSA elevation following radical prostatectomy. JAMA 1999; 281: 1591-1597.

6. Litwin MS, Tan HJ. The Diagnosis and Treatment of Prostate Cancer: A Review. Jama 2017; 317: 2532-2542.

7. Rodrigues DN, Boysen G, Sumanasuriya S et al. The molecular underpinnings of prostate cancer: impacts on management and pathology practice. J Pathol 2017; 241: 173-182.

8. Klotz L, O'Callaghan C, Ding K et al. Nadir testosterone within first year of androgendeprivation therapy (ADT) predicts for time to castration-resistant progression: a secondary analysis of the PR-7 trial of intermittent versus continuous ADT. J Clin Oncol 2015; 33: 11511156.

9. Bertaglia V, Tucci M, Fiori C et al. Effects of serum testosterone levels after 6 months of androgen deprivation therapy on the outcome of patients with prostate cancer. Clin Genitourin Cancer 2013; 11: 325-330.

10. Dason S, Allard CB, Tong J, Shayegan B. Defining a new testosterone threshold for medical castration: Results from a prospective cohort series. Can Urol Assoc J 2013; 7: E263267.

11. Kawakami J, Morales A. Clinical significance of suboptimal hormonal levels in men with prostate cancer treated with LHRH agonists. Can Urol Assoc J 2013; 7: E226-230.

12. Wang Y, Dai B, Ye DW. Serum testosterone level predicts the effective time of androgen deprivation therapy in metastatic prostate cancer patients. Asian J Androl 2016; Epub 2016 Mar 2011. 
13. Shayegan B, Pouliot F, So A et al. Testosterone monitoring for men with advanced prostate cancer: Review of current practices and a survey of Canadian physicians. Can Urol Assoc J 2017; 11: 204-209.

14. National Comprehensive Cancer Network. Development and Update of the NCCN Guidelines. https://www.nccn.org/professionals/development.aspx; Accessed December 15, 2017.

15. Network NCC. NCCN Categories of Evidence and Consensus. http://www.nccn.org/professionals/physician_gls/categories_of_consensus.asp; Accessed September 1, 2017.

16. Klotz L, Breau RH, Collins LL et al. Maximal testosterone suppression in the management of recurrent and metastatic prostate cancer. Can Urol Assoc J 2017; 11: 16-23.

17. Kamada S, Sakamoto S, Ando K et al. Nadir testosterone after long-term follow-up predicts prognosis in patients with prostate cancer treated with combined androgen blockade. J Urol 2015; 194: 1264-1270.

18. Morote J, Orsola A, Planas J et al. Redefining clinically significant castration levels in patients with prostate cancer receiving continuous androgen deprivation therapy. J Urol 2007; 178: $1290-1295$.

19. Perachino M, Cavalli V, Bravi F. Testosterone levels in patients with metastatic prostate cancer treated with luteinizing hormone-releasing hormone therapy: prognostic significance? BJU Int 2010; 105: 648-651.

20. Pickles T, Hamm J, Morris WJ et al. Incomplete testosterone suppression with luteinizing hormone-releasing hormone agonists: does it happen and does it matter? BJU Int 2012; 110: E500-507.

21. Cornford P, Bellmunt J, Bolla M et al. EAU-ESTRO-SIOG Guidelines on Prostate Cancer. Part II: Treatment of Relapsing, Metastatic, and Castration-Resistant Prostate Cancer. Eur Urol 2016; Epub 2016 Aug 2031.

22. National Comprehensive Cancer Network. NCCN Practice Guidelines in Oncology Prostate Cancer, Verson 2.2017. https://www.nccn.org/professionals/physician_gls/f_guidelines.asp\#site; Accessed September 1, 2017.

23. Schulman CC, Irani J, Morote J et al. Testosterone measurement in patients with prostate cancer. Eur Urol 2010; 58: 65-74.

24. Burger HG, Kent JR, Kellie AE. Determination of testosterone in human peripheral and adrenal venous plasma. J Clin Endocrinol Metab 1964; 24: 432-441.

25. Nishiyama T. Serum testosterone levels after medical or surgical androgen deprivation: a comprehensive review of the literature. Urol Oncol 2014; 32: 38.e17-28.

26. Oefelein MG, Feng A, Scolieri MJ et al. Reassessment of the definition of castrate levels of testosterone: implications for clinical decision making. Urol 2000; 56: 1021-1024. 
27. Wilke TJ, Utley DJ. Total testosterone, free-androgen index, calculated free testosterone, and free testosterone by analog RIA compared in hirsute women and in otherwise-normal women with altered binding of sex-hormone-binding globulin. Clin Chem 1987; 33: 1372-1375.

28. Field HP, Wheeler MJ. The measurement of androgens. Methods Mol Biol 2013; 1065: 211-226.

29. Wheeler MJ, D'Souza A, Matadeen J, Croos P. Ciba Corning ACS:180 testosterone assay evaluated. Clin Chem 1996; 42: 1445-1449.

30. Wheeler M, Barnard G. Immunoassay of steroids. In: Makin HLJ, Gower DB (eds). Steroid analysis, 2nd edn. Springer, London, pg 283-327. 2010.

31. Cao ZT, Botelho JC, Rej R, Vesper H. Accuracy-based proficiency testing for testosterone measurements with immunoassays and liquid chromatography-mass spectrometry. Clin Chim Acta 2017; 469: 31-36.

32. Miller KK, Rosner W, Lee $\mathrm{H}$ et al. Measurement of free testosterone in normal women and women with androgen deficiency: comparison of methods. J Clin Endocrinol Metab 2004; 89: 525-533.

33. Rosner W, Auchus RJ, Azziz R et al. Position statement: Utility, limitations, and pitfalls in measuring testosterone: an Endocrine Society position statement. J Clin Endocrinol Metab 2007; 92: 405-413.

34. Wang C, Catlin DH, Demers LM et al. Measurement of total serum testosterone in adult men: comparison of current laboratory methods versus liquid chromatography-tandem mass spectrometry. J Clin Endocrinol Metab 2004; 89: 534-543.

35. Herold DA, Fitzgerald RL. Immunoassays for testosterone in women: better than a guess? Clin Chem 2003; 49: 1250-1251.

36. Taieb J, Mathian B, Millot F et al. Testosterone measured by 10 immunoassays and by isotope-dilution gas chromatography-mass spectrometry in sera from 116 men, women, and children. Clin Chem 2003; 49: 1381-1395.

37. Morote J, Regis L, Celma A, Planas J. Measurement of serum testosterone during androgenic suppression in patients with prostate cancer: A systematic review. Actas Urol Esp 2016.

38. Morote J, Comas I, Planas J et al. Behavior of chemiluminescent assays to measure serum testosterone during androgen deprivation therapy. Int J Urol 2016.

39. Rosner W, Vesper H. Toward excellence in testosterone testing: a consensus statement. J Clin Endocrinol Metab 2010; 95: 4542-4548.

40. van der Sluis TM, Bui HN, Meuleman EJ et al. Lower testosterone levels with luteinizing hormone-releasing hormone agonist therapy than with surgical castration: new insights attained by mass spectrometry. J Urol 2012; 187: 1601-1606.

41. Vesper HW, Botelho JC. Standardization of testosterone measurements in humans. J Steroid Biochem Mol Biol 2010; 121: 513-519. 
42. Bui HN, Struys EA, Martens F et al. Serum testosterone levels measured by isotope dilution-liquid chromatography-tandem mass spectrometry in postmenopausal women versus those in women who underwent bilateral oophorectomy. Ann Clin Biochem 2010; 47: 248-252. 43. Vesper HW, Bhasin S, Wang C et al. Interlaboratory comparison study of serum total testosterone [corrected] measurements performed by mass spectrometry methods. Steroids 2009; 74: 498-503.

44. Vesper HW, Botelho JC, Shacklady C et al. CDC project on standardizing steroid hormone measurements. Steroids 2008; 73: 1286-1292.

45. Clinical and Laboratory Standards Institute. Liquid Chromatography-Mass Spectrometry Methods, 1st Edition (C62-A). https://clsi.org/standards/products/clinical-chemistry-andtoxicology/documents/c62/; Accessed September 1, 2017.

46. Clinical and Laboratory Standards Institute. Mass Spectrometry for Androgen and Estrogen Measurements in Serum, 1st Edition (C57). https://clsi.org/standards/products/clinicalchemistry-and-toxicology/documents/c57/; Accessed September 1, 2017.

47. UK NEQAS. External Quality Assessment Program - Steroid Hormones - Clinical Chemistry. http://ukneqas.org.uk/programmes/result/?programme=steroid-hormones; Accessed September 1, 2017.

48. Centers for Disease Control and Prevention. Hormone and Vitamin D Standardization Programs. https://www.cdc.gov/labstandards/hs.html; Accessed September 1, 2017.

49. Saad F, Chi KN, Finelli A et al. The 2015 CUA-CUOG Guidelines for the management of castration-resistant prostate cancer (CRPC). Can Urol Assoc J 2015; 9: 90-96. 


\section{Figures and Tables}

Fig. 1A. Limitations of IAs at low testosterone levels. Due to a lack of specificity, interference by serum or plasma components, particularly when testosterone levels are low (1-2), may result in inaccurate measurements. Immunoassays tend to overestimate steroid levels at low concentrations (3).

1 in the sample

Other serum or plasma components that may inhibit testosterone binding

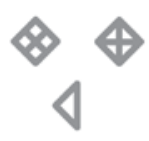

2

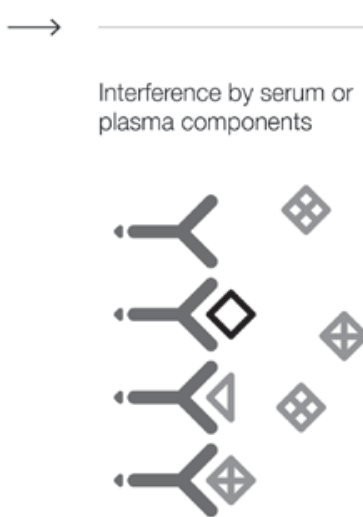

3

Testosterone measurement via chemiluminescence and potential overestimation of testosterone at low levels (i.e., below $1.7 \mathrm{nmol} / \mathrm{L}$ )

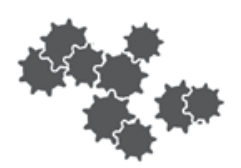

Legend

$\diamond$ Testosterone $\prec \diamond$ Immuno-complex

$\prec$ Antibody Chemiluminescent label 
Fig. 1B. High specificity and greater accuracy by LC-MS/MS at low testosterone levels.

Non-target serum components are eliminated via sample preparation and liquid chromatography (1); specificity and quantification are ensured by detection of ions (or mass-to-charge ratios) selected by the MS (2); two levels of mass separation further eliminate non-target compounds (MS/MS) (2), ensuring high specificity (3).

\section{High performance liquid} chromatography (HPLC)

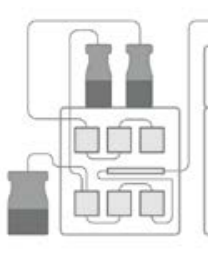

2

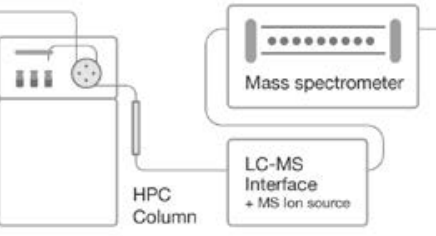

Accurate measurement at low testosterone levels

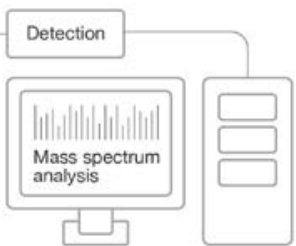


Fig 2. Management of patients on ADT with testosterone levels above target threshold of 0.7 nmol/l. * Follow CUA-CUOG guidelines [49] for management of CRPC; ADT: androgen deprivation therapy; CRPC: castration-resistant prostate cancer; PSA: prostate-specific antigen; $\mathrm{T}$ : testosterone.

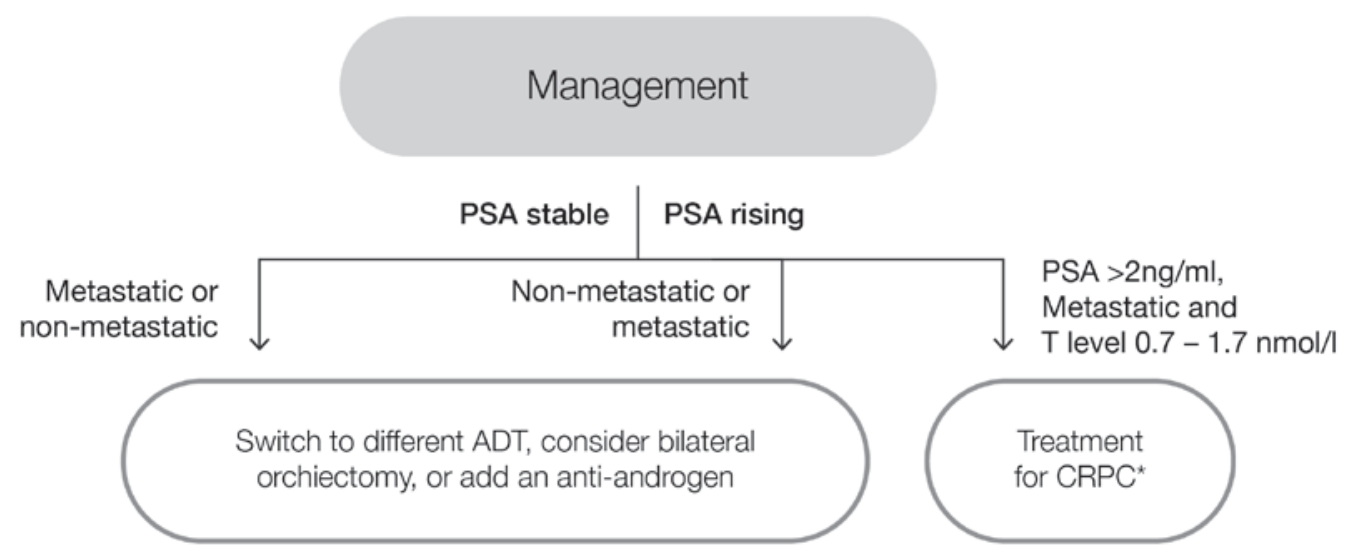

Fig. 3. Management of patients on ADT with testosterone levels at or below target threshold of 0.7 nmol/l. * Follow CUA-CUOG guidelines [49] for management of CRPC; ADT:, androgen deprivation therapy; CRPC: castration-resistant prostate cancer; PSA: prostate-specific antigen.

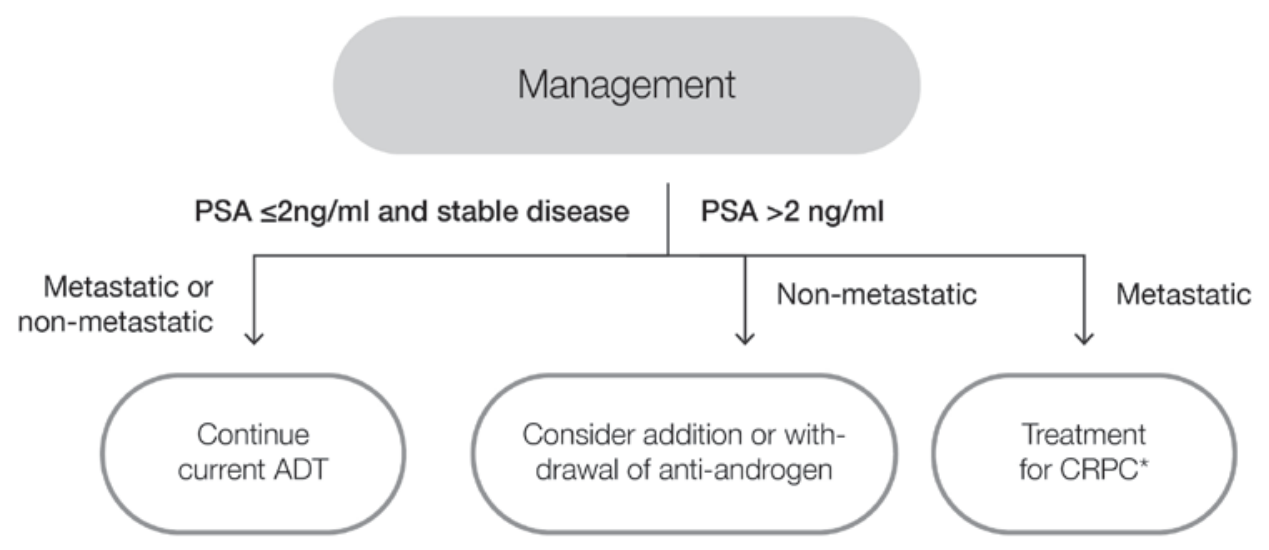


Table 1. NCCN consensus methodology [14, 15]

\begin{tabular}{|l|l|}
\hline Description & $\begin{array}{l}\text { Level of } \\
\text { consensus }\end{array}$ \\
\hline $\begin{array}{l}\text { Category 1 - Based upon high-level evidence, there is uniform } \\
\text { consensus that the intervention is appropriate }\end{array}$ & $\begin{array}{l}\text { Uniform consensus: } \\
\geq 85 \% \text { agreement }\end{array}$ \\
\hline $\begin{array}{l}\text { Category 2A - Based upon lower-level evidence, there is } \\
\text { uniform consensus that the intervention is appropriate }\end{array}$ & $\begin{array}{l}\text { Uniform consensus: } \\
88 \% \text { agreement }\end{array}$ \\
\hline $\begin{array}{l}\text { Category 2B - Based upon lower-level evidence, there is } \\
\text { consensus that the intervention is appropriate }\end{array}$ & $\begin{array}{l}\text { Non-uniform consensus: } \\
50-84 \% \text { agreement }\end{array}$ \\
\hline $\begin{array}{l}\text { Category 3 - Based upon any level of evidence, there is major } \\
\text { disagreement that the intervention is appropriate }\end{array}$ & $\begin{array}{l}\text { No consensus: } \\
<50 \% \text { agreement }\end{array}$ \\
\hline
\end{tabular}


Table 2: Prospective studies of androgen deprivation therapy outcomes by testosterone level. Adapted from Klotz et al. Maximal testosterone suppression in the management of recurrent and metastatic prostate cancer. Can Urol Assoc J 2017;11:16-23. Copyright 2017 by CUAJ. Adapted with permission.

\begin{tabular}{|c|c|c|c|c|c|}
\hline $\begin{array}{l}\text { Study } \\
\text { type/ } \\
\text { n/ } \\
\text { setting }\end{array}$ & ADT regimen(s) & T level & $\begin{array}{l}\text { Time to } \\
\text { CRPC } \\
\text { (months) } \\
\text { HR (95\% } \\
\text { CI) }\end{array}$ & $\begin{array}{l}\text { PFS } \\
\text { (months) } \\
\text { HR (95\% } \\
\text { CI) }\end{array}$ & $\begin{array}{l}\text { OS } \\
\text { (months) } \\
\text { HR (95\% CI) or } \\
\text { (range) }\end{array}$ \\
\hline \multirow{3}{*}{$\begin{array}{l}\text { Klotz } \\
\text { 2015 [8] } \\
\text { RCT, } \\
\text { Multi- } \\
\text { center } \\
626 \\
\text { Recurrent }\end{array}$} & \multirow{3}{*}{$\begin{array}{l}\text { Orchiectomy or } \\
\text { LHRHa plus } \\
\text { nonsteroidal } \\
\text { antiandrogen } \\
\text { for minimum of } 4 \\
\text { weeks }\end{array}$} & $\begin{array}{l}\leq 0.7 \mathrm{nmol} / 1 \\
(\mathrm{NT} \text { year } 1 ; \\
\mathrm{n}=489)\end{array}$ & $\begin{array}{l}10.0^{\mathrm{a}} \\
(\mathrm{yrs}) \\
\left(p=0.015^{\mathrm{b}}\right. \\
)\end{array}$ & \multirow{3}{*}{ NR } & $\begin{array}{l}\text { Not reached }^{\mathrm{a}} \\
\left(\mathrm{CSS} ; p=0.02^{\mathrm{b}}\right)\end{array}$ \\
\hline & & $\begin{array}{l}>0.7 \text { to }<1.7 \\
\text { nmol/1 }(\mathrm{NT} \\
\text { year } 1 ; \\
\mathrm{n}=129)\end{array}$ & $\begin{array}{l}7.21^{\mathrm{a}} \\
(\mathrm{yrs}) \\
1.62 \\
{[1.20-} \\
2.18]\end{array}$ & & $\begin{array}{l}10.07^{\mathrm{a}}(\mathrm{yrs}) \\
(\mathrm{CSS}) \\
2.08[1.28-3.38]\end{array}$ \\
\hline & & $\begin{array}{l}\geq 1.7 \mathrm{nmol} / \mathrm{l} \\
\text { (NT year } 1 ; \\
\mathrm{n}=8 \text { ) }\end{array}$ & $\begin{array}{l}3.62^{\mathrm{a}} \\
(\mathrm{yrs}) \\
1.90 \\
{[0.98-} \\
4.70]\end{array}$ & & $\begin{array}{l}\text { Not reached }^{\mathrm{a}} \\
(\mathrm{CSS}) \\
2.93[0.70-12.30]\end{array}$ \\
\hline \multirow[b]{2}{*}{$\begin{array}{l}\text { Wang } \\
\text { 2016 [12] } \\
\text { Single- } \\
\text { center } \\
206 \\
\text { Met }\end{array}$} & \multirow{2}{*}{$\begin{array}{l}\text { LHRHa every mo. or } \\
\text { long-acting LHRHa } \\
\text { every } 3 \text { mo. } \\
\text { Bicalutamide } 50 \\
\text { mg/day } \\
\text { Secondary HT of } \\
\text { LHRHa and flutamide } \\
250 \text { mg } 3 \text { times a day } \\
\text { after bicalutamide } \\
\text { withdrawal for } 6 \\
\text { weeks }\end{array}$} & $\begin{array}{l}\leq 0.9 \mathrm{nmol} / 1 \\
(\mathrm{n}=98)\end{array}$ & $\begin{array}{l}19.1^{\mathrm{C}} \\
(p=0.000 \\
4)\end{array}$ & & \\
\hline & & $\begin{array}{l}>0.9 \mathrm{nmol} / \mathrm{l} \\
(\mathrm{n}=108)\end{array}$ & $14.6^{\mathrm{C}}$ & NR & NR \\
\hline $\begin{array}{l}\text { Bertaglia } \\
2013[9]\end{array}$ & $\begin{array}{l}\text { LHRHa (long-acting } \\
\text { formulation) every } 3\end{array}$ & $\begin{array}{l}<0.7 \mathrm{nmol} / \mathrm{l} \\
(\mathrm{n}=25) \mathrm{vs}\end{array}$ & NR & $\begin{array}{l}\text { NR } \\
0.58\end{array}$ & $\begin{array}{l}\text { NR } \\
0.19[0.04-0.76]\end{array}$ \\
\hline
\end{tabular}


Consensus: Testosterone suppression for advanced prostate cancer

\begin{tabular}{|c|c|c|c|c|c|}
\hline $\begin{array}{l}\text { Study } \\
\text { type/ } \\
\text { n/ } \\
\text { setting }\end{array}$ & ADT regimen(s) & T level & $\begin{array}{l}\text { Time to } \\
\text { CRPC } \\
\text { (months) } \\
\text { HR (95\% } \\
\text { CI) }\end{array}$ & $\begin{array}{l}\text { PFS } \\
\text { (months) } \\
\text { HR (95\% } \\
\text { CI) }\end{array}$ & $\begin{array}{l}\text { OS } \\
\text { (months) } \\
\text { HR (95\% CI) or } \\
\text { (range) }\end{array}$ \\
\hline \multirow{3}{*}{$\begin{array}{l}\text { Single- } \\
\text { center } \\
153 \\
\text { L, LA \& } \\
\text { Met }\end{array}$} & \multirow{3}{*}{$\begin{array}{l}\text { mo. } \\
\text { Bicalutamide } 50 \mathrm{mg} \\
\text { daily } \\
\text { during the first } 4 \\
\text { weeks }\end{array}$} & $\begin{array}{l}\geq 0.7 \mathrm{nmol} / 1 \\
(\mathrm{n}=128)\end{array}$ & & $\begin{array}{l}{[0.30-} \\
1.15] \\
(\mathrm{TTP} \\
p=0.12)\end{array}$ & $(p=0.020)^{\mathrm{d}}$ \\
\hline & & $\begin{array}{l}\leq 1.0 \mathrm{nmol} / 1 \\
(\mathrm{n}=56) \mathrm{vs} \\
>1.0 \mathrm{nmol} / \mathrm{l} \\
(\mathrm{n}=97)\end{array}$ & & $\begin{array}{l}\text { NR } \\
0.76 \\
{[0.46-} \\
1.26] \\
(\mathrm{TTP} \\
p=0.30)\end{array}$ & $\begin{array}{l}\text { NR } \\
0.45[0.22-0.94] \\
(p=0.034)\end{array}$ \\
\hline & & $\begin{array}{l}<1.7 \mathrm{nmol} / \mathrm{l} \\
(\mathrm{n}=94) \mathrm{vs} \\
\geq 1.7 \mathrm{nmol} / \mathrm{l} \\
(\mathrm{n}=59)\end{array}$ & & $\begin{array}{l}\text { NR } \\
0.84 \\
{[0.52-} \\
1.37] \\
(\mathrm{TTP} \\
p=0.51)\end{array}$ & $\begin{array}{l}\text { NR } \\
0.74[0.42-1.33] \\
(p=0.32)\end{array}$ \\
\hline $\begin{array}{l}\text { Kawaka } \\
\text { mi } 2013 \\
\text { [11] } \\
\text { Single- } \\
\text { center } \\
69 \\
\text { Met }\end{array}$ & $\begin{array}{l}\text { LHRHa (goserelin, } \\
\text { leuprolide or } \\
\text { buserelin) }\end{array}$ & $\begin{array}{l}\leq 0.7 \mathrm{nmol} / 1 \\
(\mathrm{n}=56)\end{array}$ & NR & $\begin{array}{r}\text { Other res } \\
\text { PSA mini } \\
\text { median } \\
\text { higher } \mathrm{f} \\
\text { patients } \\
0.7 \text { nmo } \\
\text { PSA corre } \\
\text { (correla } \\
0.003 \text { ). } \\
\text { T levels > } \\
\text { found in } \\
\text { (4/21) a } \\
\text { patients } \\
\text { leuproli } \\
\text { respecti } \\
\text { No statist }\end{array}$ & $\begin{array}{l}\text { Ilts: } \\
\text { num, maximum, } \\
\text { nd mean were all } \\
\text { r the cohort of } \\
\text { with levels of } \mathrm{T}> \\
\text { /l. } \\
\text { lated with total T } \\
\text { on } 0.42 ; \mathrm{p}= \\
.7 \text { nmol/l were } \\
17 \%(7 / 41), 19 \% \\
\text { d 28\% (2/7) of } \\
\text { on goserelin, } \\
\text { e and buserelin, } \\
\text { ely. } \\
\text { cal difference }\end{array}$ \\
\hline
\end{tabular}



advanced prostate cancer

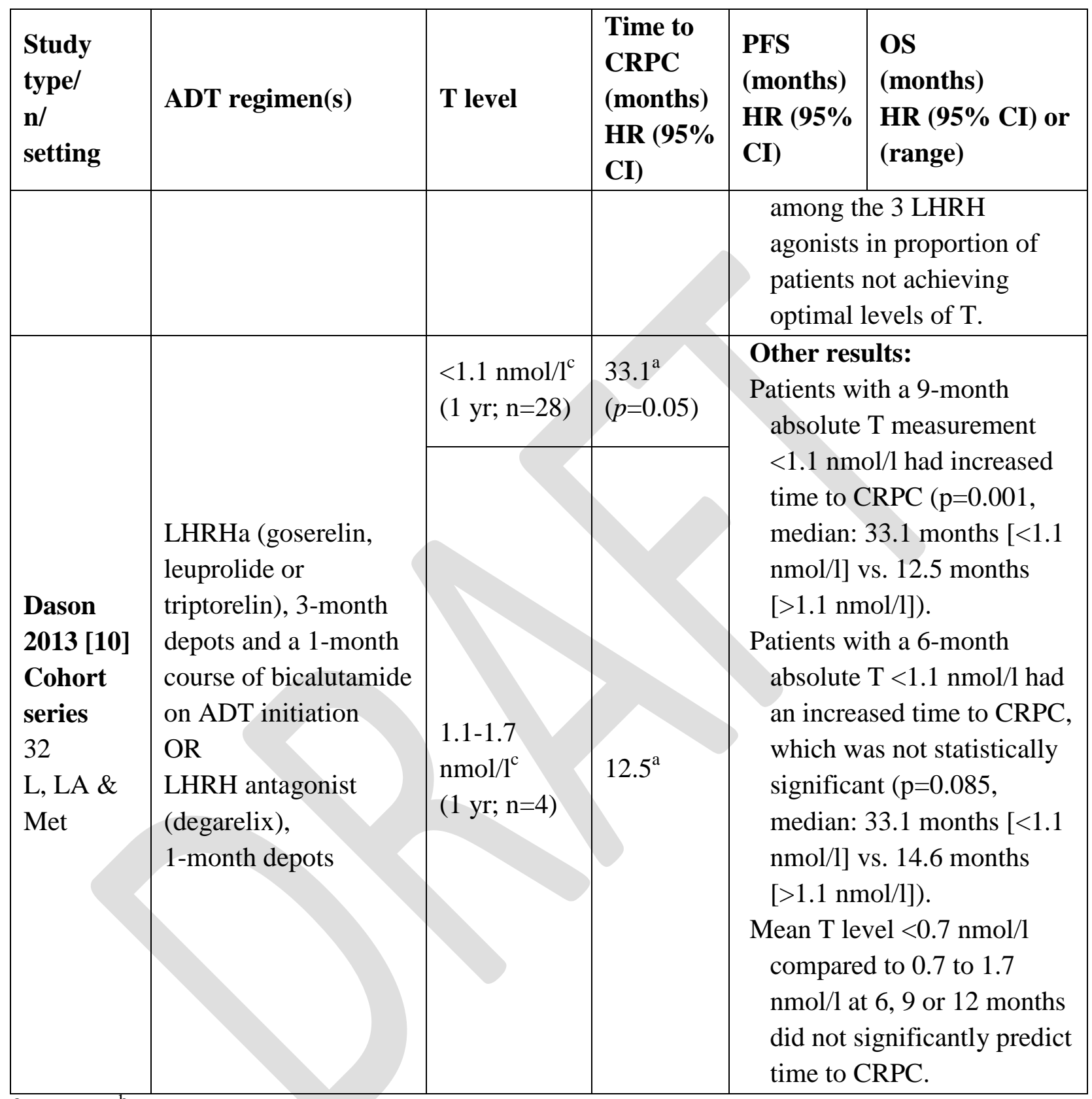

${ }^{\mathrm{a}}$ Median; ${ }^{\mathrm{b}}$ adjusted for multiple test based on the Hochberg method (Hochberg et al. Biometrics 1988; 75:800-802). ' $m e a n ; ~{ }^{d}$ serum T level $<0.7 \mathrm{nmol} / \mathrm{l}$ significantly associated with lower risk of death. ADT: androgen deprivation therapy; CI: confidence interval; CRPC: castration-resistant prostate cancer; CSS: cause (cancer)-specific survival; HR: hazard ratio; HT: hormonal therapy; L: localized; LA: locally advanced; LHRH(a): luteinizing hormone-releasing hormone (agonist); Met: metastatic; mo: month(s); NR: not reported; NT: nadir testosterone; OS: overall survival.; 
PFS: progression-free survival; PSA: prostate-specific antigen; RCT: randomized controlled trial; T: testosterone; TTP: time to progression; yr(s): year(s). 